\title{
TINGKAH LAKU SIANG HARI Cynopterus sphinx (Vahl,1797)
}

\author{
Fauziah Syamsi \\ Program Studi Pendidikan Biologi, FKIP, Universitas Riau Kepulauan, Batam \\ Koresponden: fauziasyamsi@yahoo.co.id
}

\begin{abstract}
ABSTRAK
Penelitian tentang Tingkah Laku Siang Hari Cynopterus sphinx (Vahl, 1797) telah dilakukan pada bulan Oktober 2008 dengan waktu pengamatan selama 15 hari dengan total waktu kontak pengamat dengan hewan objek penelitian adalah 150 jam. Metoda yang digunakan dalam penelitian ini adalah metoda survei dengan teknik "Continues sampling" di tempat bergantung C. sphinx pada siang hari. Hewan objek penelitian adalah sekelompok $C$. sphinx yang bergantung di pohon Cinnamomum burmanni Nees ex Bl. yang terdapat di komplek kampus jurusan Biologi FMIPA Universitas Andalas. Dari hasil penelitian diketahui bahwa tingkah laku siang hari Cynopterus sphinx (Vahl, 1797) di tempat bergantungnya berupa aktivitas istirahat sebanyak $66,17 \%$, aktivitas bergerak sebanyak $21,09 \%$, aktivitas grooming sebanyak $11,98 \%$, aktivitas mengeluarkan suara sebanyak $0,06 \%$, aktivitas agonistik sebanyak $0,56 \%$ dan aktivitas seksual sebanyak $0,13 \%$.
\end{abstract}

Kata Kunci : Tingkah Laku, aktivitas grooming, Cynopterus Sphinx

\section{PENDAHULUAN}

Kelelawar termasuk ke dalam ordo Chiroptera yang merupakan satu-satunya Mammalia yang memiliki sayap dan mempunyai kemampuan untuk terbang (Parker \& Haswell, 1978; Young, 1981; Fenton, 1992; Champbell,1999; Nowak, 1997; Payne et al , 2000). Kelelawar memiliki jumlah jenis terbanyak di bawah ordo Rodentia (Nowak, 1994). Pada beberapa daerah di Indonesia dikenal dengan paniki, niki, lawa, kampret, lalai, lowo, lawa, codot, hawa, prok, cecadu, kusing dan Tayo (Suyanto, 2001).

Penelitian tentang kelelawar yang sudah dilakukan yaitu Nurulkamilah (2002) meneliti tentang "Chiroptera di Kotamadya Padang", menemukan 21 jenis Chiroptera. Haznan (2003) meneliti "Jenis-Jenis Chiroptera pada Beberapa Gua di Sumatera Barat" memperoleh 10 jenis Chiroptera. Asmarini (2005) meneliti tentang "Chiroptera di Sipisang Kayu Tanam Sumatera Barat" menemukan 13 jenis. Selain itu juga telah ada penelitian tentang anatomi dan biologi reproduksi dari kelompok hewan ini, di antaranya adalah Sari (2008) meneliti tentang "Ukuran Tengkorak (Craniometric) pada Dua Jenis Kelelawar (Rhinolophidae : Rhinolophus)". Susanti (2008) Meneliti tentang "Pola Produksi Sperma Cynopterus sphinx di Kawasan Kampus Biologi Universitas Andalas Padang dan Kasmeri (2008) meneliti tentang "Pola Produksi Sperma Rhinolophus steno di Gua Indarung". Penelitian terhadap tingkah laku kelelawar belum banyak dilakukan. Penelitian yang pernah dilakukan adalah oleh Mailizarni (2000) tentang "Struktur Vegetasi Tempat Bergantung dan Tingkah laku Siang Hari Pteropus vampyrus di Desa Duo-Sidang Maninjau”. 
Penelitian Tingkah Laku Siang Hari Cynopterus sphinx (Vahl, 1797) belum pernah dilakukan. Sampai saat ini informasi mengenai tingkah laku kelelawar khususnya $\quad$. sphinx masih sangat kurang. Oleh karena itu dilakukan penelitian mengenai "Tingkah Laku Siang Hari Cynopterus sphinx (Vahl, 1797)". Penelitian ini bertujuan untuk mengetahui tingkah laku siang hari $C$. sphinx yang berada di pohon Cinnamomum burmanni Nees ex Bl. di kawasan komplek kampus jurusan Biologi Universitas Andalas Padang.

\section{METODE PENELITIAN}

\section{Pengamatan}

Pengamatan dilakukan berjarak \pm 10 meter dari tempat bergantung. Data kuantitatif dicatat secara "continues sampling" dengan waktu pengamatan selama 150 jam untuk mengetahui frekuensi dari masing-masing kegiatan. Pengamatan ini dilakukan dalam tiga waktu yaitu pagi, siang dan sore. Pengamatan dilakukan selama 15 hari, dilakukan mulai dari jam 07.30 WIB sampai jam 17.30 WIB dan masing-masing waktu pengamatan adalah 200 menit dengan penjadwalan yaitu: Pagi (07.30- 10.50), tengah hari (10.50-14.10) dan sore (14.10-17.30).

Substansi tingkah laku yang diamati dari hewan fokal tersebut adalah :

1. Aktivitas istirahat ("Resting"); Tidak melakukan aktivitas kecuali diam atau tidur.

2. Aktivitas bergerak; Terdiri dua kategori, yaitu:

a. Aktivitas berpindah tempat; yaitu aktivitas meninggalkan posisi tempat bergantung dengan cara berjalan atau terbang. Di antaranya adalah sebagai berikut:
a. Bertukar posisi dengan individu lain
b. Berpindah ke dahan yang lain pada pohon yang sama
c. Berpindah ke pohon atau tempat lain.

b. Aktivitas bergerak di tempat; yaitu aktivitas menggerakkan telinga, kepala, badan, sayap, mengepak-ngepakkan sayap, menukar posisi badan dan berayun.

3. Aktivitas menelisik ("Grooming"); kejadian yang termasuk kategori grooming adalah mencari parasit pada tubuh dan membelai baik yang sosial grooming maupun grooming sendiri.

4. Aktivitas mengeluarkan suara ("Vocal"); aktivitas keluarnya suara dari mulut.

5. Aktivitas agonistik

Semua kejadian yang termasuk kategori penyerangan seperti ancaman dengan membuka mulut, memburu, menggigit, dan bergulat. 
6. Aktivitas seksual; hubungan seksual antara jantan dan betina (kawin) dan melahirkan.

Pencatatan untuk semua substansi tingkah laku akan dilakukan apabila ada minimal satu individu yang melakukan aktivitas tersebut.

\section{Analisa Data}

Data yang didapatkan selama penelitian dibagi menjadi data kualitatif dan data kuantitatif. Data kualitatif diterangkan secara deskriptif dan data kuantitatif dianaliasa dengan cara menghitung frekuensi dari masing-masing kejadian atau aktivitas dengan rumus sebagai berikut:

Jumlah frekuensi suatu aktivitas

Persentase suatu aktivitas = -------------------------------------- x 100\%

Jumlah frekuensi seluruh aktivitas

\section{HASIL DAN PEMBAHASAN}

Pengamatan tentang tingkah laku siang hari Cynopterus sphinx (Vahl, 1797) ini dilakukan pada bulan Oktober 2008 dengan waktu pengamatan selama 15 hari dan total waktu kontak pengamat dengan hewan objek penelitian adalah 150 jam. Suhu rata-rata selama pengamatan adalah 26,12 oC dan kelembaban rata-rata adalah 83,37\%. Jumlah individu $C$. sphinx yang bergantung di pohon $C$. burmanni tidak selalu sama pada setiap hari pengamatan.

Jumlah terbanyak yang pernah ditemukan saat pengamatan adalah delapan ekor (Tabel 1) yang terdiri dari satu individu jantan dewasa, enam betina dewasa dan satu ekor bayi yang masih berada dalam gendongan induk betina. Jumlah paling sedikit yang ditemukan adalah tiga ekor yang terdiri dari satu ekor jantan dewasa dan dua ekor betina dewasa. Perbedaan jumlah anggota roosting ini disebabkan oleh jarak tempuh hewan ini dalam menemukan sumber makanan pada malam hari. Cope et al (1961 cit Linzey, 2001) menemukan bahwa Eptesicus fuscus (Big Brown Bats) memiliki variasi jarak terbang dari roosting. Hampir semua dari jenis ini yang terbang sejauh 32 kilometer dan kembali pada malam yang sama. Beberapa di antaranya juga terbang sejauh 64 kilometer dan tidak kembali sampai malam ke dua dan ada juga di antara mereka yang terbang sejauh 161 kilometer dari roosting dan kembali pada malam ke tiga. Individu yang terbang sejauh 403 kilometer dari roosting, beberapa di antaranya akan kembali pada malam ke empat dan hampir semuanya kembali pada malam ke lima. 
Selama pengamatan tidak ditemukan individu muda ("juvenile") yang bergantung bersama pada roosting site yang diamati, namun pada hari ke sembilan pengamatan ditemukan dua individu muda yang bergantung pada roosting site lain pada pohon yang sama dengan kelompok yang menjadi objek penelitian. Kedua individu muda ini diduga baru saja pergi dari roosting induk. Kehadiran kedua juvenile yang membuat roosting baru ini hanya terdeteksi selama satu kali pengamatan dan tidak terlihat lagi pada hari pengamatan berikutnya. Diduga kedua juvenile merasa tidak cocok dengan lokasi tersebut dan mencari lokasi baru untuk ditempatinya. C. sphinx bergantung di roosting secara bersama dan menumpuk seperti sebuah rumpun atau tandan buah. Umumnya pada pagi hari, individu jantan dan betina akan tergabung dalam satu rumpun dan saat sinar matahari mulai terik, individu jantan menjauh diri dari rumpun dan bergantung terpisah. Saat cahaya matahari bersinar terik, beberapa betina yang tergabung dalam rumpun tersebut akan menjauh beberapa langkah dari betina lainnya tapi masih berdekatan. Perpindahan jantan dari tandan roosting ini bertujuan untuk melindungi betina dari serangan predator pada siang hari karena individu jantan merupakan pemimpin dalam sebuah harem (Alcock, 2001). Dari pengamatan yang telah dilakukan, diperoleh total persentase tingkah laku siang hari $C$. sphinx adalah seperti Gambar 1 berikut ini:

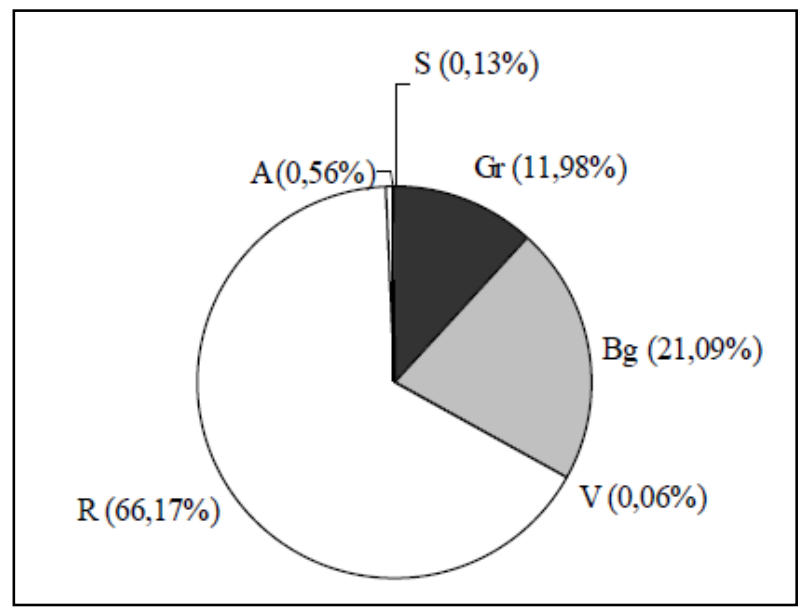

Keterangan: $\mathrm{A}=$ Agonistik, $\mathrm{Bg}=$ Bergerak, $\mathrm{Gr}=$ Grooming, $\mathrm{R}=$ Resting, $\mathrm{S}=$ Seksual,$\quad \mathrm{V}=$ Vocal

Gambar 1. Total persentase aktivitas siang hari Cynopterus sphinx (Vahl, 1797)

Dari Gambar 1 di atas dapat dilihat bahwa pada siang hari C. sphinx lebih banyak menghabiskan waktunya untuk beristirahat, yaitu dengan persentase $66,17 \%$, yaitu melebihi setengah dari total aktifitas yang dilakukannya pada siang hari. C. sphinx menggerakkan tubuhnya pada siang hari sebanyak 21,09\% dan melakukan aktivitas grooming sebanyak 11,98\%. Kegiatan agonistik, seksual, dan mengeluarkan suara (“vocal”) sangat jarang teramati, persentase untuk masing-masing kegiatan tesebut adalah $0,56 \%, 0,13 \%$ dan $0,06 \%$. 


\section{Aktivitas istirahat ("Resting")}

Istirahat merupakan kegiatan yang paling banyak dilakukan oleh hewan nokturnal seperti kelelawar pada siang hari. Aktivitas istirahat tertinggi $C$. sphinx terjadi pada waktu pagi yaitu sebanyak $34,34 \%$ dan menurun pada tengah hari $(33,41 \%)$ dan sore $(32,25 \%)$ seperti terlihat pada Gambar 2. C. sphinx beristirahat dengan kedua kakinya menggantung pada cabang pohon dan tubuh tertutup atau diselimuti kedua sayap. Jarang sekali hewan ini menggantung dengan menggunakan satu kaki dan sayap terbuka pada saat istirahat. Persentase aktivitas istirahat pada masing-masing waktu pengamatan dapat dilihat pada Gambar 2 berikut ini:

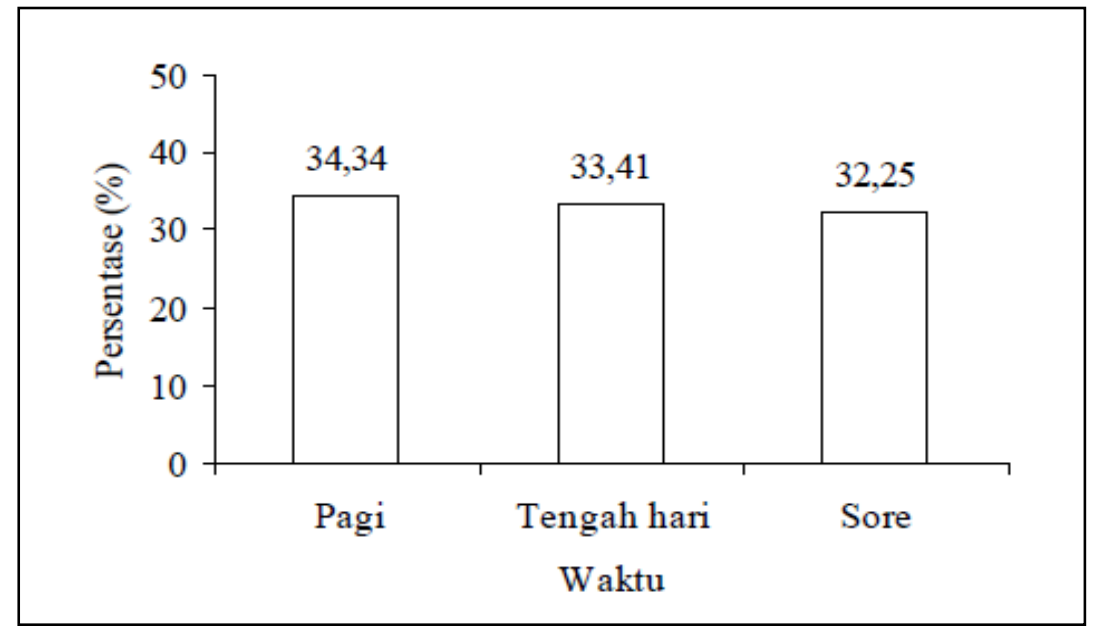

Gambar 2. Persentase aktivitas istirahat $C$. sphinx pada tiap waktu pengamatan.

Pada saat istirahat di roosting, posisi kepala umumnya tidak beraturan, ada yang menghadap ke cahaya matahari, menyamping dan membelakangi matahari. Betina yang terdiri dari 2-6 individu menggantung dengan posisi muka yang tidak searah, di antaranya adalah saling menyamping, berhadapan dan saling membelakangi. Individu jantan paling sering roosting terpisah dari individu betina dengan posisi berhadapan dengan kelompok betina. Posisi ini digunakan oleh jantan untuk mengawasi betina saat istirahat.

Kegiatan istirahat ini mengawali kelelawar untuk tidur. Kegiatan yang selalu terlihat sebelum dan setelah tidur adalah membuka mulut lebar-lebar (menguap). Ekspresi mengantuk sangat terlihat jelas dari wajah hewan ini. Novick (1969) mengemukakan bahwa istirahat merupakan permulaan untuk tidur. "Flying fox" (genus Pteropus ) selalu kuap dengan sangat lebar sebelum tidur. Aktifitas istirahat terbanyak terjadi pada pukul 08.30-09.30 yaitu sebesar $10,44 \%$ dan terendah pada pukul 16.30-17.30 (akhir jam pengamatan) sebesar 8,82\%. Hal ini disebabkan karena waktu aktif hewan ini adalah pada malam hari sehingga pada sore hari hewan cenderung akan lebih aktif karena telah terpengaruh oleh sifat nokturnalnya. 


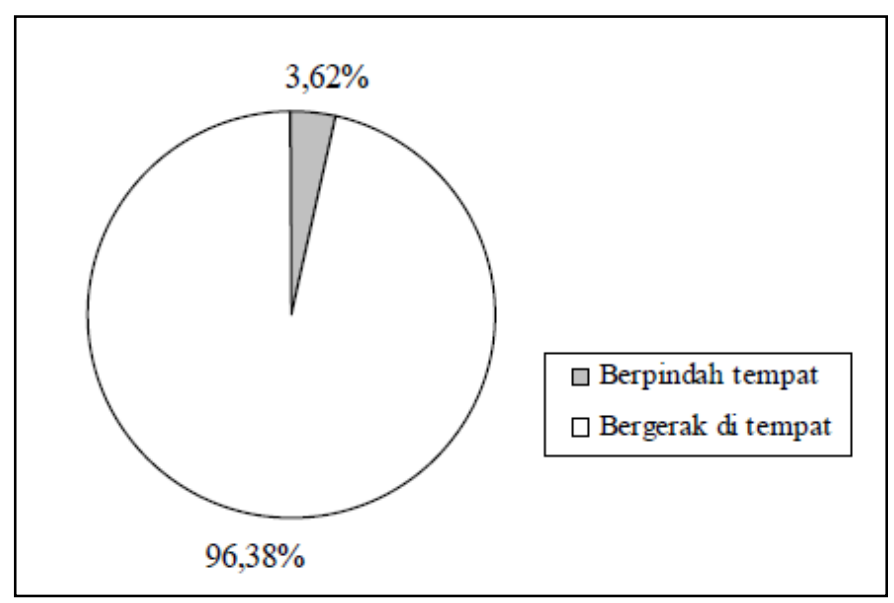

Gambar 3. Persentase aktivitas istirahat $C$. sphinx pada tiap jam pengamatan

\section{Aktivitas bergerak}

Pergerakan merupakan ciri khas hewan (Campbell, 1999). Hal ini bertujuan untuk mendapatkan makanan, rumah dan sarang yang cocok serta untuk menghindari periode yang tidak menguntungkan. Selain itu pergerakan juga berguna dalam menentukan pasangan kawin (Linzey, 2001). Aktivitas bergerak C. sphinx dapat terlihat pada Gambar 4 berikut ini:

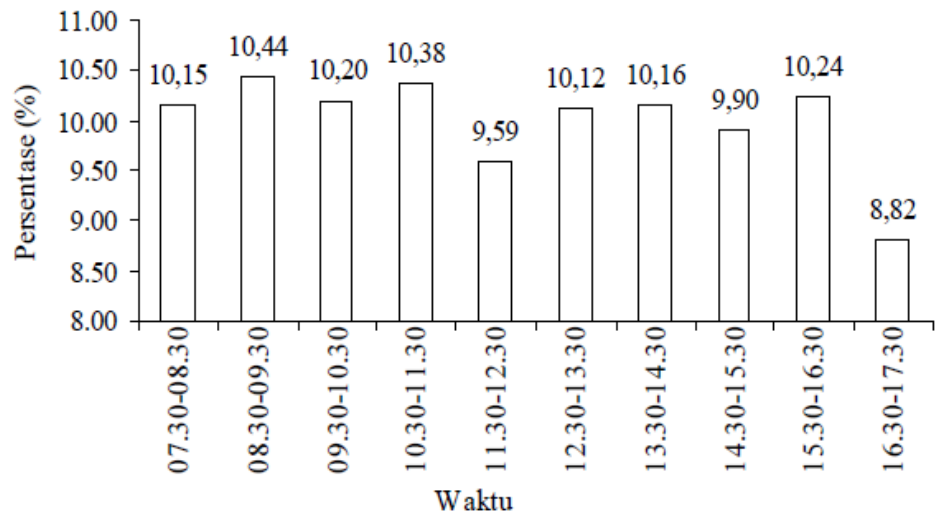

Gambar 4. Persentase aktivitas bergerak C. sphinx pada siang hari.

Dari Gambar 4 di atas dapat dilihat bahwa C. sphinx jarang sekali bergerak berpindah tempat saat berada di roosting pada siang hari. C. sphinx berpindah tempat sebanyak 3,62\% dari keseluruhan aktivitas bergerak yang dilakukannya dan 96,38\% digunakan untuk bergerak di tempat dengan menggerakkan bagian-bagian tubuhnya seperti telinga, sayap dan kaki. $C$. sphinx jarang berpindah tempat pada siang hari disebabkan oleh jam aktif dari hewan ini adalah pada malam hari (nokturnal) dan mobilitas sesungguhnya terjadi pada malam hari. 


\section{Aktivitas berpindah tempat}

Berpindah tempat dilakukan karena beberapa hal, di antaranya adalah karena cuaca sudah panas, terjadi pertengkaran dengan individu lain atau memberi ruang kepada anak sehingga pindah dan menjauh beberapa langkah dari kelompok. Berpindah tempat paling sering dilakukan oleh jantan dewasa di pagi hari saat matahari mulai bersinar terik. Dari pengamatan, jantan dewasa selalu berpindah tempat saat cahaya matahari mulai panas. Jantan dewasa tersebut menjauh beberapa langkah dari roosting yang awalnya bergabung dengan betina dan anaknya. Selama pengamatan, betina dewasa juga berpindah tempat tetapi masih pada roosting utama.

Induk betina lebih sering berpindah tempat dibandingkan betina lainnya. Perpindahan induk ini biasanya jelas terlihat karena berjarak beberapa langkah dari kelompok individu betina lainnya. Perpindahan ini bertujuan untuk mencari tempat yang agak lapang sehingga bisa memberi ruang gerak yang cukup bagi anak yang berada di dalam lipatan sayap induk serta meminimalisir gangguan dari betina lain terhadap anak. Persentase masing-masing kategori berpindah tempat dapat dilihat pada Gambar 5 berikut ini:

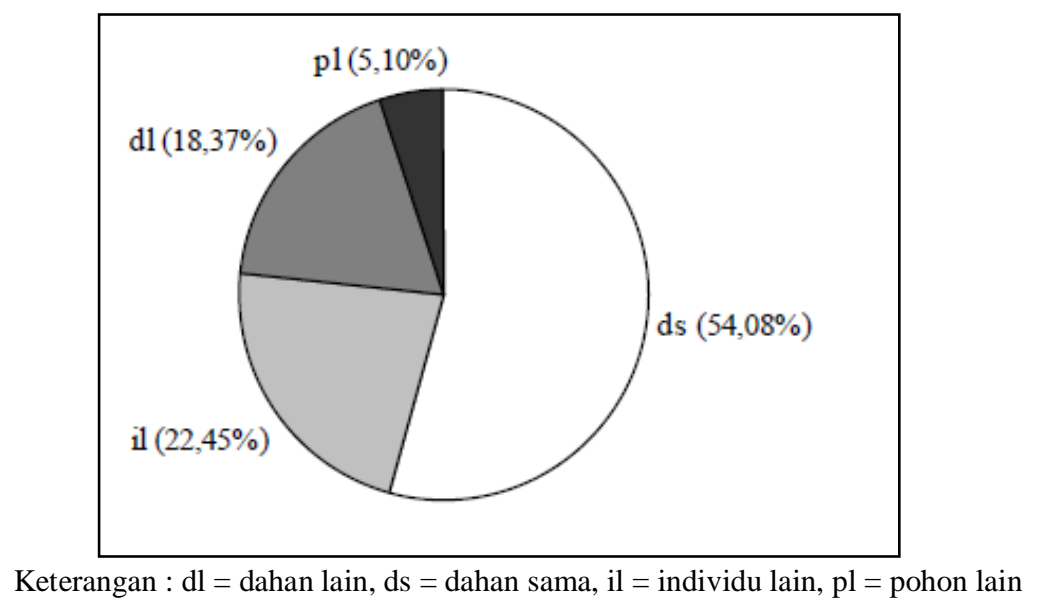

Gambar 5. Persentase masing-masing ketegori berpindah tempat $C$. sphinx pada siang hari.

Gambar 5 dapat diketahui bahwa $C$. sphinx lebih banyak berpindah pada dahan yang sama, yaitu sebanyak 54,08\%. Dari pengamatan, berpindah tempat pada dahan yang sama terjadi tidak terlalu jauh dari roosting utama. Jarak terjauh selama pengamatan adalah tujuh langkah dari hewan ini.

Berpindah ke dahan lain teramati sebanyak 18,37\%. Perpindahan ke dahan lain ini biasanya dilakukan oleh betina yang memiliki bayi dan individu jantan saat memisahkan diri dari kelompok betina. Dari semua kategori berpindah tempat, berpindah ke pohon atau tempat lain sangat jarang teramati, hanya $5,1 \%$ dari total kegiatan berpindah tempat. C. sphinx pindah 
ke pohon dan tempat lain saat ada gangguan, baik yang berasal dari kelompok sendiri seperti terjadi perkelahian antar anggota kelompok ataupun gangguan dari hewan lain dan manusia yang berada di sekitar lokasi roosting. Perpindahan ini tidak berlangsung lama. Setelah keadaan dirasakan aman, individu yang berpindah tempat akan kembali ke roosting utama.

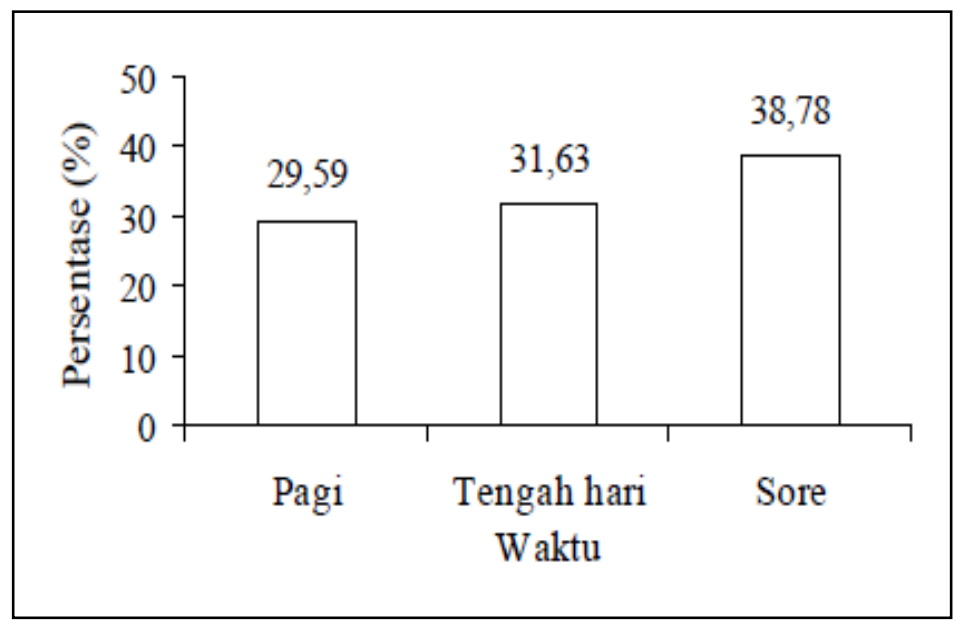

Gambar 6. Persentase aktivitas berpindah tempat C. sphinx pada tiap waktu pengamatan.

Dari Gambar 6 dapat dilihat bahwa kegiatan berpindah tempat tertinggi terjadi pada sore hari, yaitu sebanyak 38,78\% dan terendah pada pagi hari yaitu 29,59\%. Perpindahan yang dilakukan oleh $C$. sphinx ini meliputi berjalan dengan posisi menggantung ke arah samping dan depan. Berbeda halnya dengan genus Pteropus, hewan ini pernah berpindah dengan berjalan mundur pada satu ranting dengan menggunakan kedua kaki dan kedua ibu jarinya. Hewan ini juga ditemukan berjalan dengan menggunakan ibu jarinya dan kedua kaki menggantung di udara. Posisi ini merupakan kebalikan dari posisi yang sesungguhnya bagi kelelawar (Novick, 1969; Mailizarni, 2000).

Berpindah tempat yang dilakukan oleh C. sphinx yaitu dengan dua cara, yaitu berjalan dengan menggunakan kedua kaki dan yang kedua adalah merangkak dengan menggunakan kombinasi kaki dan dan cakar pada anggota gerak depan untuk berpindah tempat, sehinga kedua kaki dan cakar menggantung pada cabang pohon dan posisi badan terlihat melengkung. Hal ini juga dilakukan oleh Rousettus aegyptiacus berjalan ke depan pada sebuah ranting dengan menggunakan kaki dan lengan dimana jari kaki sebelah kiri digunakan secara bebas (Novick, 1969). Berpindah tempat pada tiap jam pengamatan dapat dilihat pada Gambar berikut: 


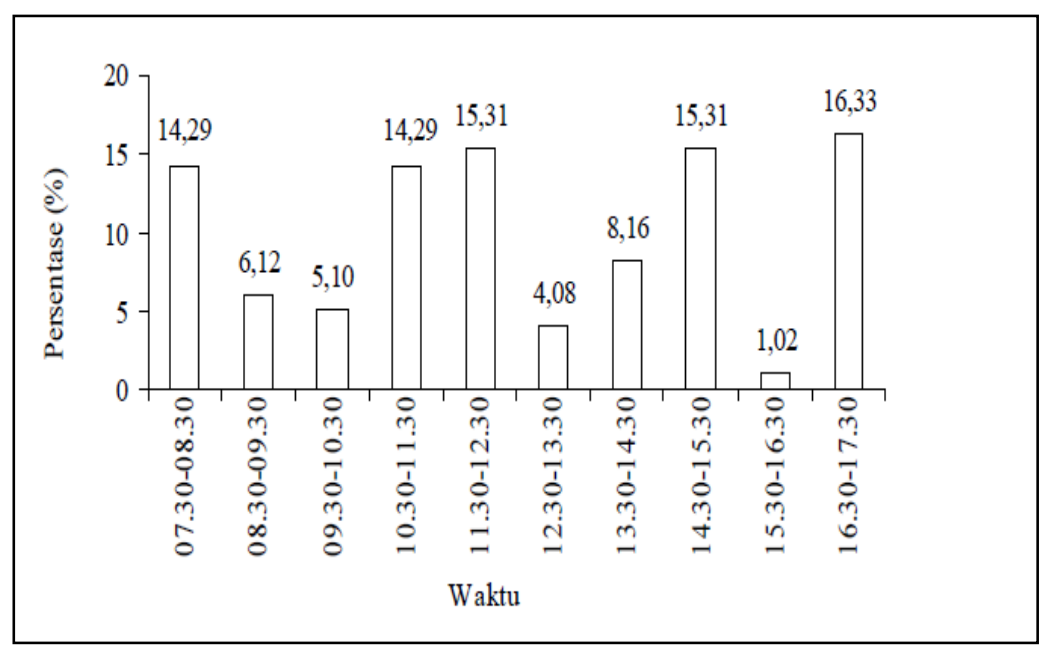

Gambar 7. Persentase aktivitas berpindah tempat $C$. sphinx pada tiap jam pengamatan.

Seperti terlihat pada Gambar 7, C. sphinx aktif berpindah tempat pada rentang waktu tertentu saja. Pada awal pengamatan persentase berpindah tempat cukup tinggi yaitu $14,29 \%$ dan terjadi penurunan pada pukul 08.30-10.30. Rentang waktu pukul 10.3012.30 terjadi peningkatan mencapai $15,31 \%$ kemudian aktivitas ini kembali menurun pada pukul 12.30-13.30 menjadi 4,08\%. Pada rentang waktu 13.30-15.30 terjadi peningkatan lagi menjadi $8,16 \%$ dan dan $15,31 \%$. Pada pukul $15.30-16.30$ terjadi penurunan yang sangat drastis, yaitu menjadi 1,02\% dari total kegiatan berpindah tempat. Namun pada akhir jam pengamatan, persentase kegiatan ini kembali meningkat tajam menjadi 16,33\%.

\section{Aktivitas bergerak di tempat}

Telinga merupakan organ yang paling sensitif bagi kelelawar karena merupakan organ reflek yang penting (Novick, 1969). Setiap suara yang terdengar disekitar lokasi roosting selalu ditanggapi oleh kelelawar dengan menggerak-gerakan telinganya. Gerakan ini menandakan bahwa $C$. sphinx bisa mendengar suara tersebut. Intensitas suara yang terlalu tinggi mengakibatkan hewan ini terkejut dan bisa terbang meninggalkan roosting sampai keadaan kembali normal.

Gerakan lain yang cukup sering dilakukan adalah berayun. Kegiatan ini biasanya dilakukan sebagai pendahuluan sebelum melakukan suatu kegiatan dan paling sering terjadi sebelum melakukan kegiatan grooming dan berpindah tempat. 


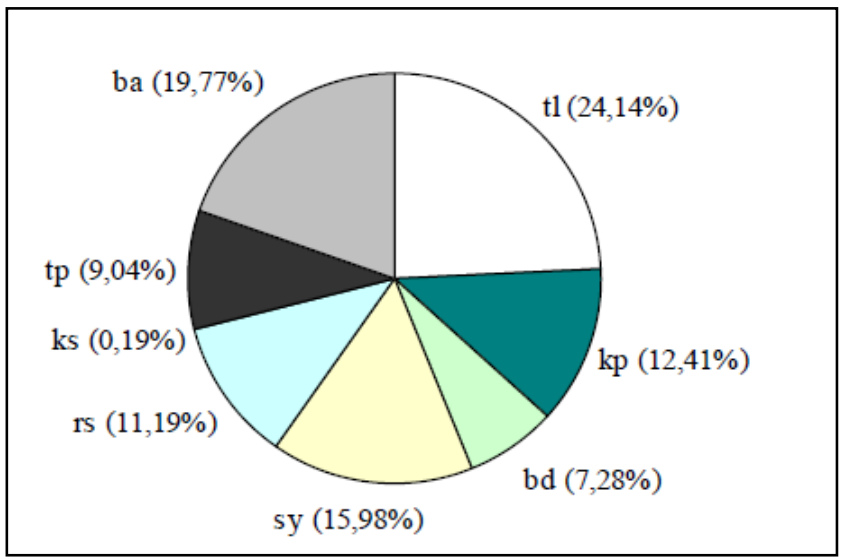

Keterangan: $\mathrm{tl}=$ telinga, $\mathrm{kp}=$ kepala, $\mathrm{bd}=$ badan, $\mathrm{sy}=$ sayap, $\mathrm{rs}=$ rentang sayap, $\mathrm{ks}=$ kepak sayap, $\mathrm{tp}=$ tukar posisi, ba = berayun

Gambar 8. Persentase di tempat $C$. sphinx dari total aktivitas bergerak di tempat masingmasing kategori bergerak

Kegiatan berayun ini dilakukan sebanyak $19,77 \%$ dari total kegiatan bergerak. Aktivitas bergerak yang paling jarang terlihat selama waktu pengamatan adalah mengepakkan sayap yaitu sebanyak 0,19\%. Persentase aktivitas bergerak di tempat dapat dilihat pada Gambar 9 berikut ini :

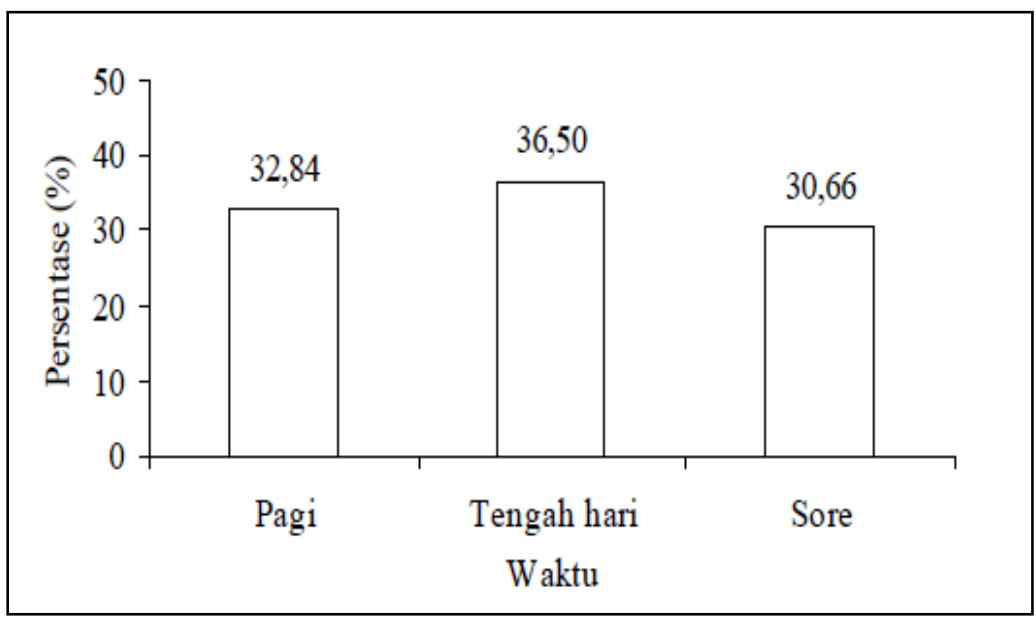

Gambar 9. Persentase aktivitas bergerak di tempat C. sphinx pada masing-masing waktu pengamatan dari total akitvitas bergerak

C. sphinx aktif bergerak sepanjang waktu pengamatan. Aktivitas bergerak tertinggi terjadi pada tengah hari, yaitu sebanyak $36,50 \%$ dan terendah pada sore hari yaitu sebanyak $30,66 \%$. Persentase aktivitas bergerak di tempat pada tiap jam pengamatan dapat dilihat pada Gambar 10 berikut ini: 


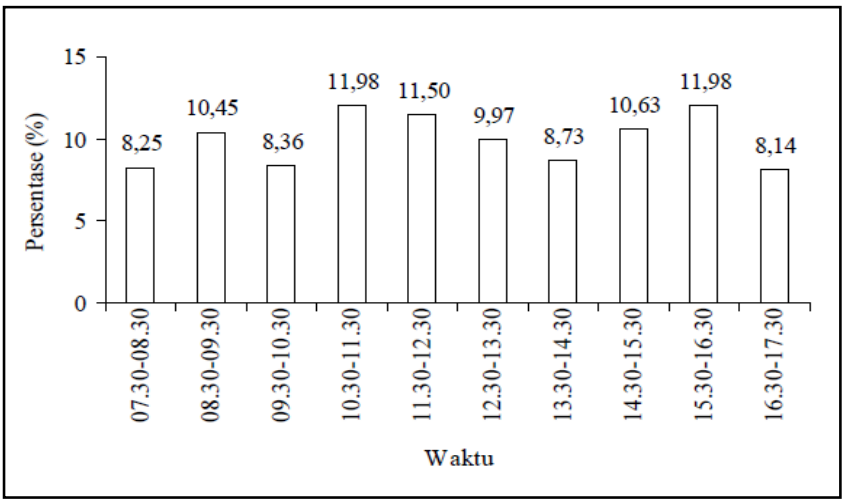

Gambar 10. Persentase aktivitas bergerak di tempat $C$. sphinx pada tiap jam pengamatan

Persentase aktivitas bergerak pada tiap jam menunjukkan $C$. sphinx selalu melakukan pergerakan tubuh pada tiap jam dengan persentase yang tidak tetap. Persentase bergerak tertinggi terjadi pada pukul 11.30-12.30 dan 15.30-16.30, yaitu sebanyak $11,98 \%$ dan terendah terjadi pada akhir jam pengamatan, yaitu sebanyak $8,14 \%$.

Aktivitas mengganti posisi tubuh juga sering dilakukan oleh hewan ini, di antaranya bertukar arah menggantung dan melipatkan badan ke bagian ventral sehingga kepala berada di posisi atas. Posisi ini digunakan untuk membuang kotorannya. Membuang kotoran dengan cara membalikkan posisi tubuh ke atas ini bertujuan untuk menghindari tubuh hewan dari kotoran yang dikeluarkannya (Fenton, 1992).

\section{Aktivitas menelisik ("grooming")}

Aktivitas menelisik (grooming) terjadi pada setiap saat. Dimulai ketika C. sphinx mulai bergantung di pagi hari sampai saat akan terbang mencari makan pada senja hari. Grooming tertinggi terjadi pada sore hari yaitu sebanyak 40,54\% dan terendah pada pagi hari sebanyak $25,11 \%$. Aktivitas grooming yang dilakukan C. sphinx pada masing-masing waktu pengamatan dapat dilihat pada Gambar 11 berikut.

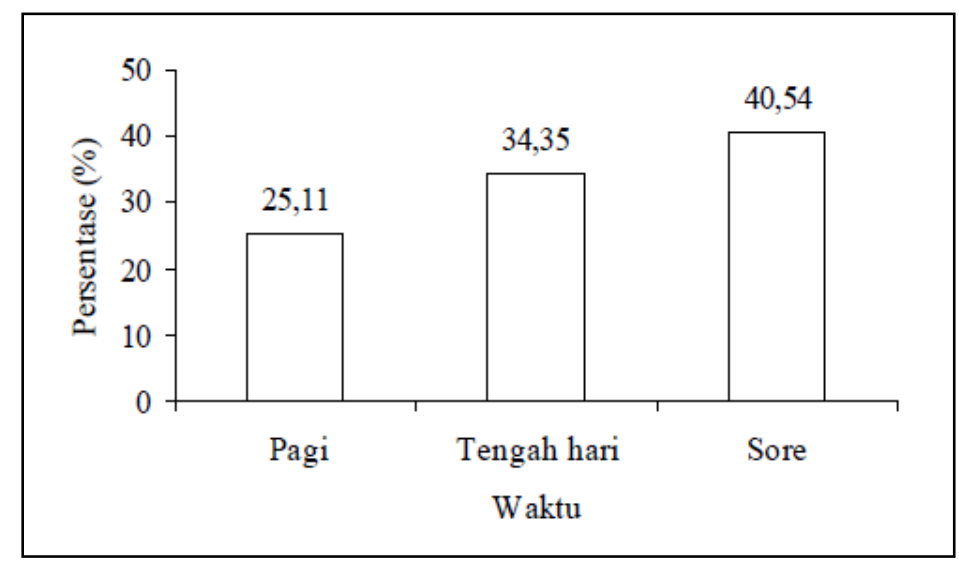

Gambar 11. Persentase aktivitas grooming $C$. sphinx pada tiap waktu pengamatan. 
Dari pengamatan juga terlihat kegiatan menggroming anak yang dilakukan oleh induk betina. Anak bergantung di perut induk betina dan saat mengrooming anak, induk akan membuka sayap dan membiarkan anak keluar dari tutupan sayap induk. Tubuh anak dibersihkan oleh induk dengan merentang kedua sayap anak dan menjilati tubuh bagian ventral dan dorsal. Bagian yang paling sering dibersihkan induk adalah bagian ventral karena posisi bergantung anak yang berhadap-hadapan dengan induk. Grooming merupakan kegiatan yang paling sering dilakukan oleh $C$. sphinx setelah istirahat. Persentase grooming pada tiap jam pengamatan dapat dilihat pada Gambar 12.

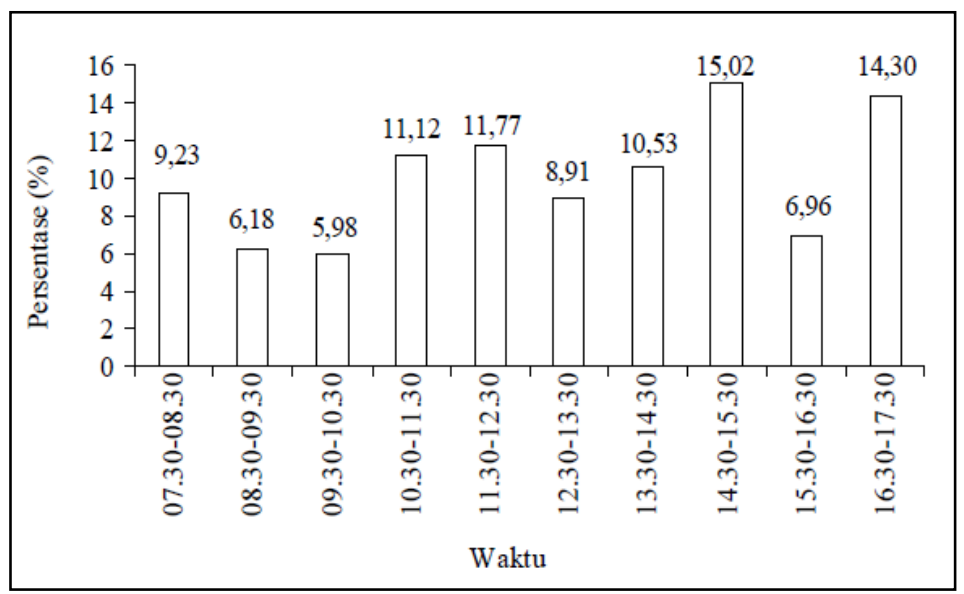

Gambar 12. Persentase aktivitas grooming C. sphinx pada tiap jam pengamatan.

Dari Gambar 13 dapat dilihat bahwa aktivitas grooming tertinggi terjadi pada pukul 14.30-15.30, yaitu sebanyak 15,02\% dari keseluruhan aktivitas grooming C. sphinx pada siang hari. Grooming terendah terjadi pada pukul 09.30-11.30 yaitu sebanyak 5,98\%.

Kegiatan grooming yang dilakukan hewan ini adalah menggaruk seluruh bagian tubuh termasuk telinga dan tubuh bagian belakang dengan menggunakan cakar dan kaki. Hal ini senada dengan yang dikemukakan oleh Fenton (1992) bahwa kelelawar membesihkan badan dengan menggunakan kuku jari kaki, lidah dan gigi. Gerakan menggaruk ini bisa sangat lambat dan sangat cepat sekali. C. sphinx juga menjilati tubuhnya berulang kali untuk membuang ektoparasit dan menjaga kelembaban rambutnya pada siang hari. Novick (1969) mengemukakan bahwa "Giant African" ( Hipposideros commersoni gigas) melakukan grooming setiap hari dengan membersihkan tubuhnya dengan cakar dan jari kaki dan membasahkan tubuh dengan lidah dan bibir setelah menyikat rambutnya. Selain itu juga menggunakan cakar untuk membersihkan daun hidung. 


\section{Aktivitas mengeluarkan suara ("Vocal")}

Aktivitas mengeluarkan suara merupakan aktivitas yang paling sedikit teramati selama waktu pengamatan. Aktivitas mengeluarkan suara paling sering terjadi pada tengah hari, yaitu 60\% dari total aktivitas mengeluarkan suara (Gambar 13) dan terendah pada pagi hari, yaitu sebanyak $10 \%$ dari total aktivitas mengeluarkan suara.

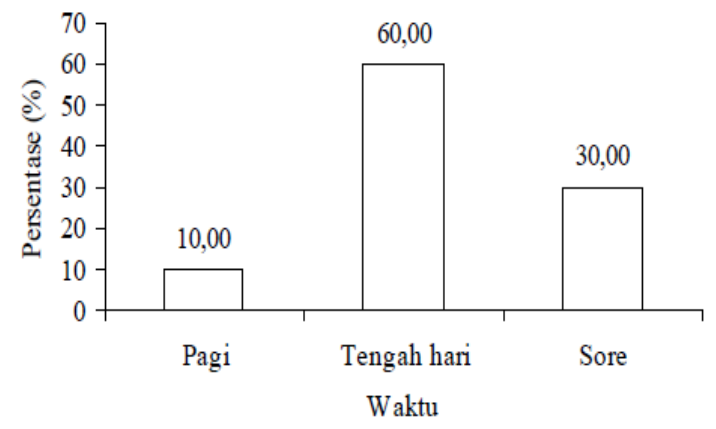

Gambar 13. Persentase aktivitas mengeluarkan suara C. sphinx pada tiap waktu pengamatan.

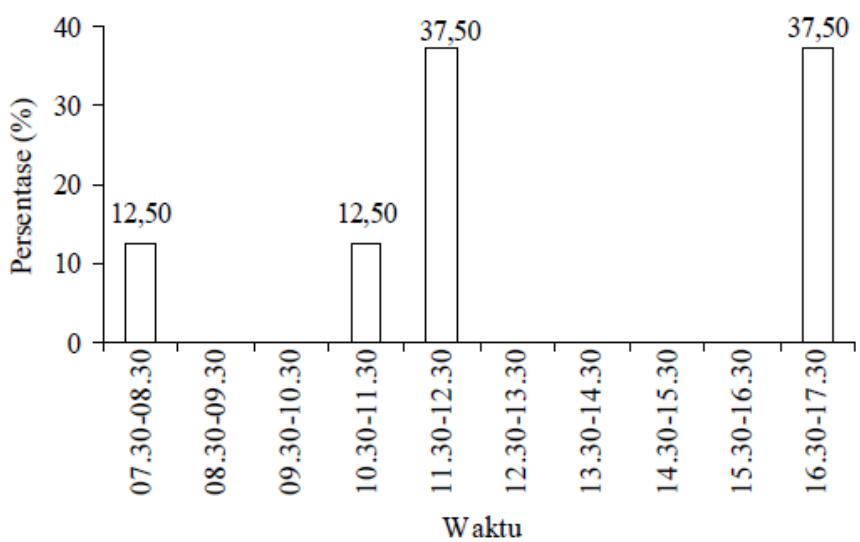

Gambar 14. Persentase aktivitas mengeluarkan suara $C$. sphinx pada tiap jam pengamatan.

Hewan ini mengeluarkan suara pada siang hari apabila menemukan kondisi yang terasa mengancam jiwanya. Hal ini senada dengan aktivitas agonistik yang terjadi, dimana aktivitas agonistik tertinggi juga terjadi pada tengah hari (Gambar 15). Suara yang dikeluarkan berupa pekikan yang agak panjang dan melengking. Suara terdengar saat hewan ini terbang setelah menyadari ada gangguan. Fenton (1992) mengemukakan bahwa suara merupakan salah satu alat komunikasi bagi kelelawar.

\section{Aktivitas agonistik}

Agonistik merupakan suatu pertandingan yang melibatkan perilaku yang mengancam maupun yang patuh. Menentukan pesaing mana yang mendapatkan akses ke beberapa sumber daya seperti makanan dan pasangan kawin. Kadang-kadang 
pertandingan tersebut melibatkan pengujian kekuatan secara lebih umum, kontestan yang terlibat melihatkan perilaku mengancam, yang membuat mereka kelihatan besar dan seram. Seringkali dengan membuat postur atau suara yang dibesar-besarkan (Campbell, 1999).

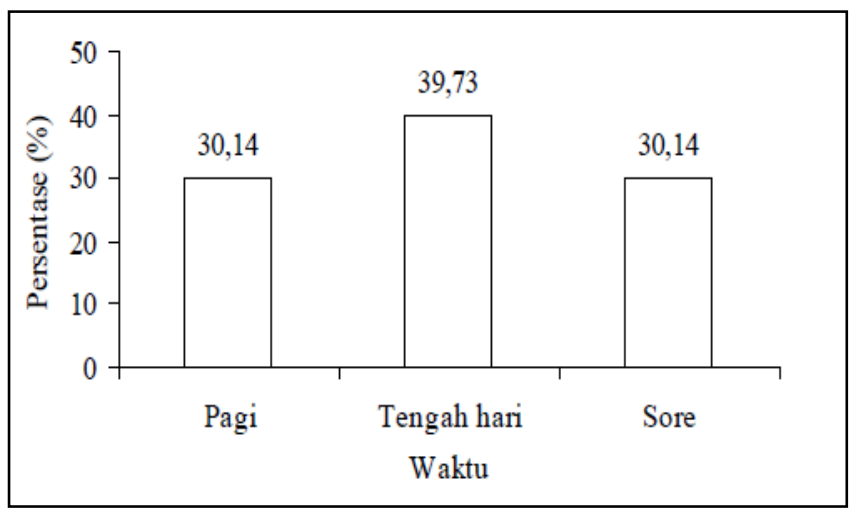

Gambar 15. Persentase aktivitas agonistik C. sphinx pada tiap waktu pengamatan.

Perilaku agonistik jarang sekali teramati, dari keseluruhan aktivitas C. sphinx pada siang hari, hanya terlihat sebanyak $0,56 \%$. Kegiatan agonistik tertinggi terjadi pada siang hari, yaitu sebanyak $39,73 \%$ dan persentase pada pagi dan sore hari adalah $30,14 \%$ dari total aktivitas agonistik.

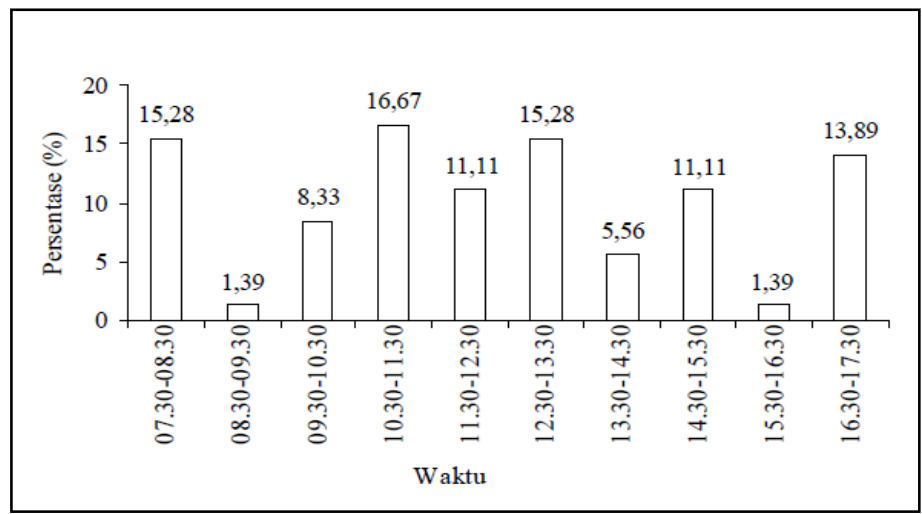

Gambar 16. Persentase aktivitas agonistik C. sphinx pada tiap jam pengamatan.

Aktivitas agonistik yang dilakukan oleh $C$. sphinx pada siang hari menunjukkan nilai yang sangat beragam. Aktivitas terendah terjadi pada pukul 08.30-09.30 dan 15.30-16.30 yaitu sebesar 1,39\% dari total aktivitas agonistik dan tertinggi terjadi pada pukul 10.30-11.30 yaitu sebesar $16,67 \%$. Betina dewasa paling sering memberikan ancaman terhadap jantan dewasa.

Perilaku mengancam ini dimulai dengan mencakar tubuh ("recipient") dengan cakar pada sayap, kemudian diikuti dengan cakaran dengan kaki. Individu yang diancam melakukan respon dengan menutupi sebagian besar kepala (terutama bagian wajah) dengan 
menggunakan sayap. Perilaku menutupi kepala dengan sayap ini membuat ("agresor") menghentikan serangannya karena merasa lawan sudah menyerah. Saat individu yang diancam kembali memperlihatkan wajahnya, ("agresor") kembali menyerang secara bertubitubi sehingga lawan kembali ke posisi pertahanan.

Kegiatan ini baru berhenti apabila lawan mengambil inisiatif untuk bertukar posisi badan membelakangi atau pindah beberapa langkah menjauhi ("agresor"). Campbell (1999) mengemukankan bahwa satu individu akan berhenti mengancam dan mengakhirinya dengan menunduk atau bersikap tenang yang pada dasarnya adalah menyerah.

\section{Aktivitas Seksual}

Seperti terlihat pada Gambar 17 dan18, aktivitas seksual tertinggi terjadi pada sore hari yaitu 47,37\% dan terendah pada pagi hari, yaitu sebanyak 15,79\%. Aktivitas seksual yang terlihat saat pengamatan adalah aktivitas menarik pasangan dengan cara memperlihatkan kegagahan kepada betina. Saat betina dewasa grooming, maka jantan dewasa merentang sayap selebar mungkin dan bertahan dengan posisi tersebut. Kemudian rambut yang terdapat di wajah dan sekitar leher mengembang sehingga memperlihatkan kegagahan jantan. kejadian ini terulang beberapa kali selama betina "grooming". Kadang-kadang diikuti dengan agonistik oleh betina karena tidak menerima jantan pada saat itu untuk melakukan perkawinan.

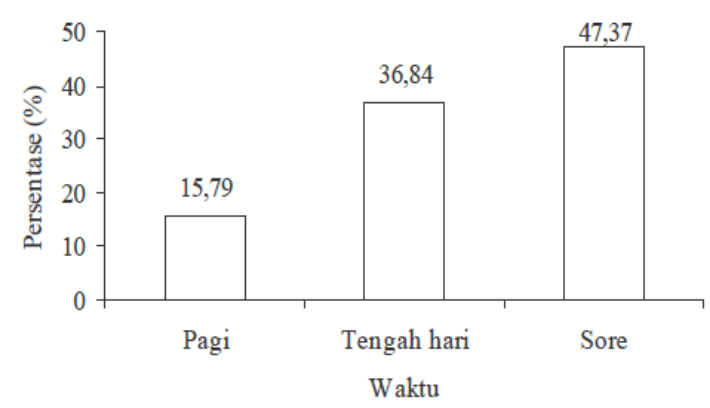

Gambar 17. Persentase aktivitas seksual C. sphinx pada tiap waktu pengamatan

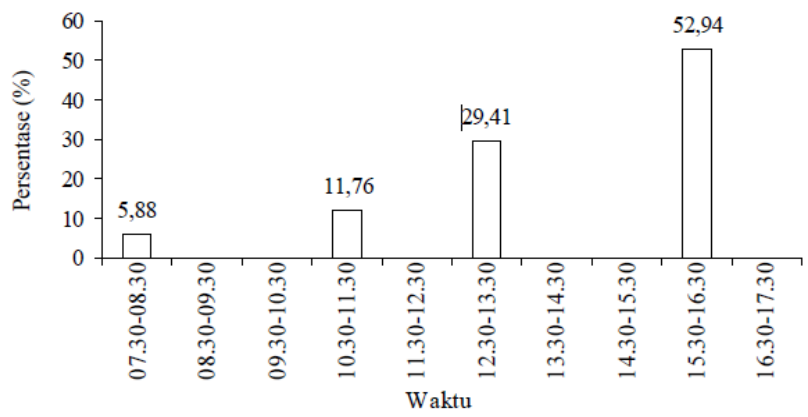

Gambar 18. Persentase aktivitas seksual C. sphinx pada tiap jam pengamatan. 


\section{Hubungan induk dengan anak ("infant")}

Pada pengamatan ditemukan satu individu betina dewasa yang memiliki anak. Pada saat berada di roosting, anak (bayi) selalu digendong pada bagian ventral tubuh dengan posisi kepala ke bawah. Posisi ini memudahkan anak untuk menemukan putting susu ("nipple") induk saat haus atau lapar. Tubuh bayi secara keseluruhan selalu diselimuti dengan sayap induk dan hanya beberapa kali dibiarkan keluar dari tutupan sayap induk, yaitu saat grooming, belajar berjalan dan sesekali pada saat menyusu.

Saat berada dalam tutupan sayap induk, anak biasanya tidur dan istirahat sambil menyusu kepada induk. Kelelawar adalah satu-satunya Mammalia yang menyusui sampai anaknya berukuran hampir dewasa (Kunz, 1987 cit Gopukumar et al , 2003). Bayi Megachiroptera menyusu kepada ibunya sampai mencapai $28,9-73,5 \%$ dari berat tubuh individu dewasa dan 76,8 - 87,7 \% dari ukuran skeletal individu dewasa (Barclay, 1995 cit Gopukumar et al , 2003). Bayi C. sphinx menyusu kepada ibu mereka sampai 10-15 hari setelah mereka mulai terbang (Shandu, 1984 cit Gopukumar et al , 2003), dan dipandu oleh ibu mereka selama permulaan terbang mencari makan (Radamani, 1996 cit Gopukumar et al, 2003).

Belajar berjalan yang terlihat selama pengamatan adalah berjalan tertatih-tatih (seperti merayap) dengan menggunakan kedua sayap dan kaki pada bagian ventral tubuh induk dengan posisi kepala tetap kearah bawah. Saat anak bergerak aktif, induk merentang sayap untuk memberikan ruang kepada anak untuk belajar berjalan.

Pada hari kehadiran induk dan anak berikutnya, keahlian anak semakin bertambah yaitu dengan memanjat tubuh induk dari bagian luar sayap induk. Pada kehadiran berikutnya terlihat tingkah laku yang sangat menarik sekali dari hubungan antara induk dengan anak yaitu terlihat induk sedang berusaha mengajarkan cara bergantung pada cabang pohon kepada anak.

\section{KESIMPULAN}

Dari hasil yang diperoleh, dapat disimpulkan bahwa tingkah laku siang hari Cynopterus sphinx (Vahl, 1797) di tempat bergantungnya berupa aktivitas istirahat sebanyak $66,17 \%$, aktivitas bergerak sebanyak $21,09 \%$, aktivitas grooming sebanyak 11,98 \%, aktivitas mengeluarkan suara sebanyak $0,06 \%$, aktivitas agonistik sebanyak 0,56\% dan aktivitas seksual sebanyak $0,13 \%$. 


\section{REFERENSI}

Alcock, J. 2001. Animal Behavior. Seventh edition. Sinauer Associates, Inc. USA.

Annonymous. 2006. Cynopterus sphinx. Short- Nosed Fruit Bat. http://www.bio.bris.ac.uk/research/bats/China\%20bats//index.htmv. 3 Maret 2006.

Asmarini. 2005. Chiroptera di Sipisang Kayu Tanam Sumatera Barat Skripsi Sarjana Biologi Fakultas Matematika dan Ilmu Pengetahuan Alam UniversitasAndalas. Padang.

Campbell, R. \& Mitchell. 2004. Biologi. Erlangga. Jakarta.

Corbet, G. B. and J. E. Hill, 1992. The Mammals of the Indomalayan Region: ASystematic Review. Oxford University Press. Oxford.

Fenton, M. B. 1992.Bats. Facts on File. New York.

Fujita, M. 1988. Flying Foxes and Economics Vol 6.Http//www.batcon.org/batsmag/vga 1-2 html. 3 maret 2007.

Gopukumar, N., P. T. Nathan, P.S. Doss, A. Prakash, K. Emmanuel, J. Balasingh, G. Marimuthu dan T.H. Kunz. 2003. Early ontogeny of foraging behaviourin theshortnosed fruit bat Cynopterus sphinx (Megachiroptera). Mammalia, 67 :139-145.

Haznan, D. 2003. Jenis-Jenis Chiroptera pada Beberapa Gua di Sumatera Barat.Skripsi Sarjana Biologi Fakultas Matematika dan Ilmu Pengetahuan AlamUniversitas Andalas. Padang.

Nurulkamilah, S. N. 2002. Chiroptera di Kotamadya Padang. Skripsi SarjanaBiologi Fakultas Matematika dan Ilmu Pengetahuan Alam UniversitasAndalas. Padang.

Kasmeri, R. 2008. Pola Produksi Sperma Rhinolophus steno di Gua Indarung.Skripsi Sarjana Biologi Fakultas Matematika dan Ilmu Pengetahuan AlamUniversitas Andalas. Padang.

Kunz, T. H. and E. D. Pierson. 1994. Bats of the World. The John HopkinsUniversity Press. Baltimore and London.

Kunz, and Storz. 1999. Mamalian species (Cynopterus sphinx). Journal Americansociety of mammalogists.

Macdonal, D. 1984. The Encyclopedia of Mammals. George Allen and Unwin.London.

Mailizarni. 2000. Struktur Vegetasi Tempat Bergantung dan Tingkahlaku Siang HariPteropus vampyrus di Desa Duo-Sidang Maninjau. Skripsi Pascasarjana Biologi Fakultas Matematika dan Ilmu Pengetahuan Alam UniversitasAndalas. Padang.

Novick, A. 1969. The World of Bats. Holt, Rinehart And Winston. New York,Chicago, San Fransisco.

Nowak, R. M. 1994. Walker's Bats of the World. The John Hopkins University Press. Baltimore and London. 
Nowak, R.M. 1997. Walker's Mammals of of the World. John Hopkins UniversityPress. Boltimore and London.

Parker, T. J \& Haswell, W. A. 1978. Text book of Zoology: Vertebrates. Seventhedition. Macmillan Press. London. Hal: 754.

Payne, J. C.M. Francis, K. Phillips, S.N. Kartikasari. 2000. Panduan LapanganMamalia Di Kalimantan, Sabah, Sarawak, dan Brunei Darussalam. Primacenter. Jakarta.

Sari, M. P. 2008. Ukuran Tengkorak (Craniometric) Pada Dua Jenis Kelelawar(Rhinolophidae : Rhinolophus). Skripsi Sarjana Biologi Fakultas Matematikadan Ilmu Pengetahuan Alam Universitas Andalas. Padang.

Shefferly, N. 1999. "Cynopterus sphinx" (On-line), Animal Diversity Web.

http://animaldiversity.ummz.umich.edu/site/accounts/information/Cynopterus sphinx.html. 4 September 2007.

Susanti, S. 2008. Pola Produksi Sperma Cynopterus sphinx di Kawasan KampusBiologi Universitas Andalas Padang. Skripsi Sarjana Biologi FakultasMatematika dan Ilmu Pengetahuan Alam Universitas Andalas. Padang.

Suyanto, A. 2001. Seri Panduan Lapangan Kelelawar di Indonesia. Puslitbang-LIPI.Bogor.

Young, J .Z. 1981. The Life of Vertebrates. Clarendon Press. Oxford. Hal. 439. 